\title{
EFFECTS OF SLAB ROLLBACK ACCELERATION ON AEGEAN EXTENSION
}

\section{Brun J.-P. ${ }^{1}$, Faccenna C. ${ }^{2}$, Gueydan F. ${ }^{3}$, Sokoutis D. ${ }^{4,5}$, Philippon M. ${ }^{6}$, Kydonakis K. ${ }^{1}$ and Gorini C. ${ }^{\text {}}$}

${ }^{1}$ Université Rennes 1, Géosciences Rennes, UMR 6118 CNRS, bat. 15 - Campus de Beaulieu, 263 Av du général Leclerc, BP 74205, 35042, Rennes Cedex, France, jean-pierre.brun@univ-rennes1.fr, konstantinos.kydonakis@outlook.com

${ }^{2}$ LET, Laboratory of Experimental Tectonics, Università Roma Tre, Rome, Italy, claudio.faccenna@uniroma3.it

${ }^{3}$ Université de Montpellier 2. Géosciences Montpellier, UMR5243, Université de Montpellier, Rue Eugène Bataillon, France, frederic.gueydan@univ-montp2.fr

${ }^{4}$ Department of Earth Sciences, Faculty of Geosciences, Utrecht University, Budapestlaan 4, PO Box80021, 3508 Utrecht, The Netherlands, D.Sokoutis@uu.nl

${ }^{5}$ Department of Geosciences, University of Oslo, PO Box 1047, Blindern, N-0316 Oslo, Norway, D.Sokoutis@uu.nl

${ }^{6}$ Université des Antilles, Géosciences Montpellier, UMR 5243, Campus de Fouillole, 97159, Pointe à Pitre, France, Melodie.Philippon@gm.univ-montp2.fr

${ }^{7}$ Sorbonne Universités, UPMC Univ Paris 06, UMR 7193, ISTeP, F-75005, Paris, France, christian.gorini@upmc.fr

\begin{abstract}
Aegean extension is a process driven by slab rollback that, since $45 \mathrm{Ma}$, shows a twostage evolution. From Middle Eocene to Middle Miocene it is accommodated by localized deformation leading to i) the exhumation of high-pressure metamorphic rocks from mantle to crustal depths, ii) the exhumation of high-temperature rocks in core complexes and iii) the deposition of Paleogene sedimentary basins. Since Middle Miocene, extension is distributed over the whole Aegean domain giving a widespread development of onshore and offshore Neogene sedimentary basins. We reconstructed this two-stage evolution in $3 D$ at Aegean scale by using available ages of metamorphic and sedimentary processes, geometry and kinematics of ductile deformation, paleomagnetic data and available tomographic models. The restoration model shows that the rate of trench retreat was around $0.6 \mathrm{~cm} / y$ during the first 30 My and then accelerated up to $3.2 \mathrm{~cm} / y$ during the last $15 \mathrm{My}$. The sharp transition observed in the mode of extension, localized versus distributed, which occurred in Middle Miocene correlates with the acceleration of trench retreat and is more likely a consequence of the Hellenic slab tearing documented by mantle tomography. The development of large dextral NE-SW strike-slip faults during the second stage of Aegean extension, since Middle Miocene, is illustrated by the $450 \mathrm{Km}$-long fault, recently put in evidence, offshore from Myrthes to Ikaria and onshore from Izmir to Balikeshir, in western Anatolia. Therefore, the interaction between the Hellenic trench retreat and the westward displacement of Anatolia started in Middle Miocene,
\end{abstract}


almost 10 Ma before the propagation of the North Anatolian Fault in the North Aegean. This raises a fundamental issue concerning the dynamic relationship between slab tearing and Anatolia displacement.

Keywords: Blueschists, core-complexes, basins.

\section{Introduction}

The Aegean Tertiary tectonic history, from a dynamic point of view, corresponds to back-arc extension driven by slab rollback (Royden, 1993; Jolivet and Faccenna, 2000; Faccenna et al., 2003, 2014; Brun and Faccenna, 2008). Extension started around 45 Ma ago (Brun and Sokoutis, 2010) and accommodated up to $600 \mathrm{~km}$ of trench retreat (Jolivet and Brun, 2010; Jolivet et al., 2013). Extension followed the closure of the two oceanic domains of Vardar and Pindos in CretaceousEocene (Dercourt et al., 1993; Channell and Kozur, 1997; Robertson, 2004) leading to the stacking of three continental blocks that from top to base are: Rhodopia, Pelagonia and Adria (Fig. 1).
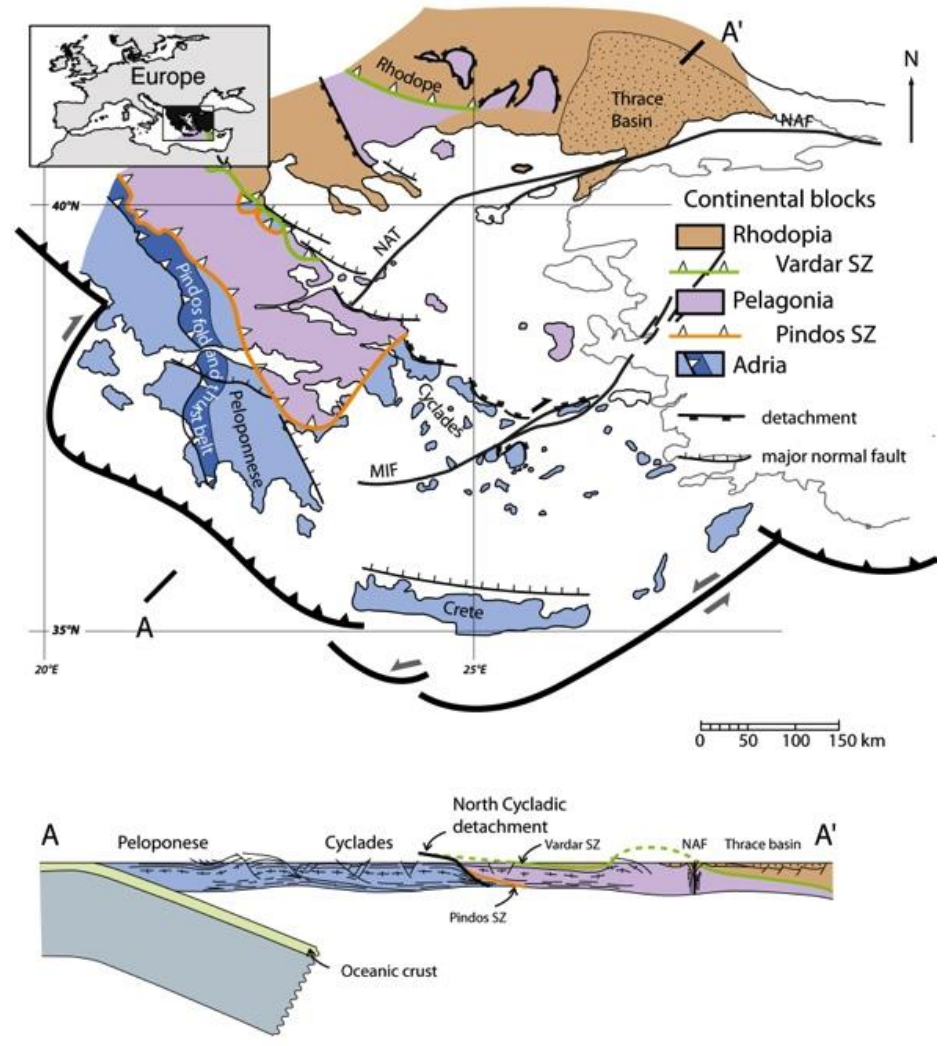

Figure 1 - The three main continental blocks of Aegean: Rhodopia, Pelagonia and Adria.

Tomographic models of the underlying mantle image a single slab (e.g. Wortel and Spakman, 2000; Piromallo and Morelli, 2003; Widiyantoro et al., 2004) indicating that the convergence of continental blocks, now separated by two suture zones, has been accommodated by a single subduction. During subduction rollback, the Pelagonia and Adria crust panels were fully detached 
from the downgoing lithospheric mantle and moved back to surface, resting directly on top of asthenosphere (Brun and Faccenna, 2008; Tirel et al., 2013).

In the present study we show that Aegean extension occurred in two main stages, from Middle Eocene to Middle Miocene and since Middle Miocene. The significant large-scale features that characterized these two stages of extension are defined in terms of sedimentation, deformation and metamorphism. It is argued i) that the major dynamic change that occurred in Middle Miocene, resulted from an acceleration of trench retreat that is more probably responsible for the observed transition between localized and distributed modes of extension and ii) that the likely cause of this acceleration due to slab tearing coeval with the onset of Anatolia westward displacement.

\section{The two main stages of Aegean extension}

The first plate kinematic models of eastern Mediterranean (McKenzie, 1972, 1978; Le Pichon and Angelier, 1981) and the present-day displacement field from satellite geodesy (McClusky et al., 2000; Hollenstein et al., 2008; Müller et al., 2013) show that the active Aegean extension results from the combined effects of the southwestward retreat of the Hellenic trench and the westward displacement of Anatolia along the North Anatolian Fault (NAF).

The geological record shows that this interaction between two strongly oblique components of boundary displacement started in Middle Miocene (Dewey and Şengör, 1979; Şengör et al., 2005; Philippon et al., 2014), around 10 My before the NAF reached the Aegean (Armijo et al., 1999; Hubert-Ferrari et al., 2003; Şengör et al., 2005). On the other hand, the coeval extensional exhumation of high-pressure metamorphic rocks in the Southern Hellenides and high-temperature metamorphic rocks in the Rhodope (Brun and Sokoutis, 2007; Brun and Faccenna, 2008) started in Middle Eocene (see review of data in Jolivet and Brun, 2010 and Philippon et al., 2012). This brief summary of the Aegean extension history during a large part of the Tertiary indicates a process that has not been continuous, neither in time nor in space. This is illustrated by a striking difference in the distribution of Paleogene and Neogene sedimentary basins at Aegean scale (Fig. 2) suggesting that a major change in the dynamics of Aegean extension occurred in Middle Miocene, more $30 \mathrm{My}$ after its onset.

\subsection{Stage 1: Paleogene basins and ductile exhumation of metamorphic rocks}

Paleogene basins (Fig. 2a) that mostly contain Middle Eocene and/or Oligocene sediments are located i) on top of the Rhodopia block (Trace Basin: Görür and Okay, 1996; Siyako and Huvaz, 2007; Kilias et al., 2013); Vardar-Thermaikos Basin: Roussos, 1994; Carras and Georgala, 1998) and ii) on top of Pelagonia (Mesohellenic Trough: Doutsos et al., 1994; Ferrière et al., 2004) (Fig. 2a).

The exhumation of core complexes (high-temperature metamorphism) and blueschists (highpressure metamorphism) (Figs. 3 and 4) resulted from significantly different mechanisms of development, primarily controlled by temperature-dependent rheology of the crustal units. 


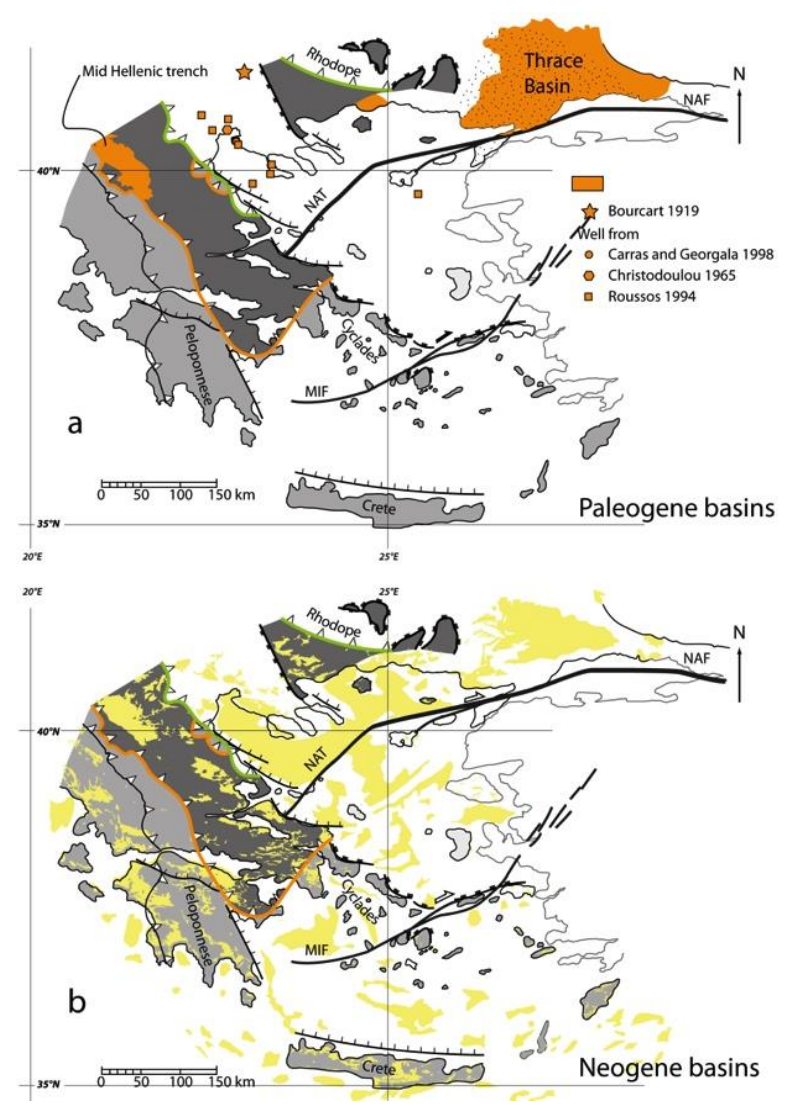

Figure 2 - Distribution of Paleogene (a) and Neogene (b) basins in the Aegean domain.

The location of core complexes and high pressure belts in the Aegean, as well as their relative timing of exhumation, has important dynamic implications:

- The Southern Rhodope Core Complex (SRCC) (Brun and Sokoutis, 2007) started to develop in Middle-Late Eocene in North Aegean when the Cycladic Blueschist Unit (CBU) started to exhume in central Aegean (Jolivet and Brun, 2010; Philippon et al., 2012).

- The Central Cyclades Core Complex (CCCC) (Philippon et al., 2012) developed in central Aegean almost synchronous with the exhumation onset of HP-LT Phyllite-Quartzite Nappe (PQN) in Peloponnese and Crete (Jolivet et al., 2010).

- The sense of shear and detachment dip, in core complexes, and sense of shear, in highpressure rocks, is top to SW in North Aegean (SRCC) (Brun and Sokoutis, 2007), to NE in central Aegean (CBU and CCCC) (Philippon et al., 2012) and to E and N in South Aegean (HP-LT PQN) (Jolivet et al., 2010).

- The part of exhumation synchronous with ductile deformation ended in Middle Miocene in all types of metamorphic rocks, either high-temperature (SRCC and CCCC) or high pressure (CBU and HP-LT PQN) and whatever age of onset. 


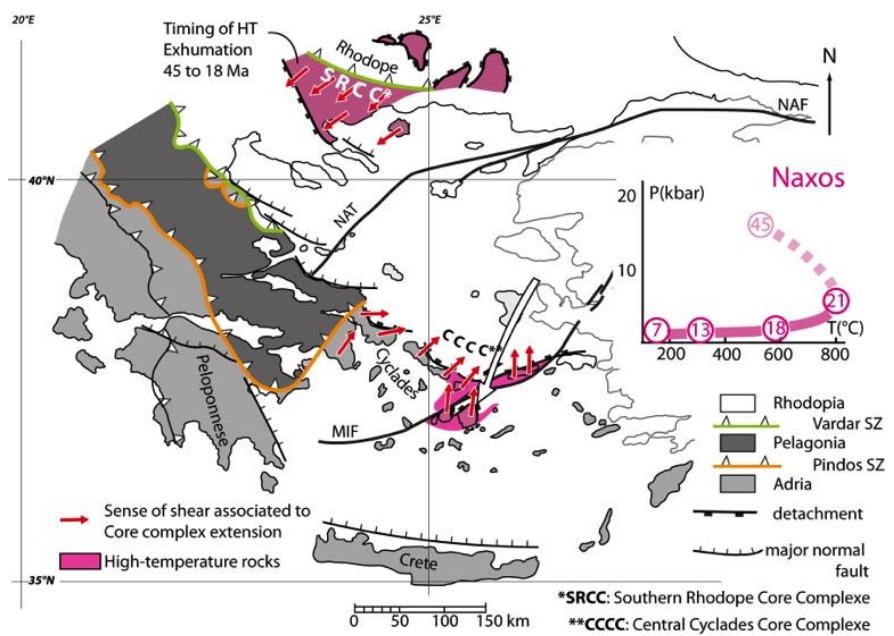

Figure 3 - The two core complexes (HT metamorphism) of the Aegean domain with corresponding PTt diagrams and related senses of shear.

\subsection{Stage 2: Neogene basins and dextral transtensional faulting}

The Neogene basins (Fig. 2b) whose deposition started in Middle Miocene constitute one of the most striking geological features of the Aegean domain, both onshore and offshore. They emplaced on all types of rock units (Paleogene basins, high-temperature or high-pressure metamorphic units, plutonic massives and volcanic buildups) of Rhodopia, Pelagonia and Adria and over around 1000 $\mathrm{km}$ from Crete to Rhodope. The earlier deposits are Langhian-Serravalian in some basins but Tortonian sediments are present in most of them. Where structural data are available, field measurements or seismics, tectonic setting of most basins is extensional or transtensional (e.g. Mercier et al., 1987, 1989; Lyberis, 1984; Mascle and Martin, 1990; Koukouvelas and Aydin, 2002; Sakellariou et al., 2013).

Low-temperature thermochronology ages, obtained by various methods (apatite and zircon fissiontrack and $\mathrm{U}-\mathrm{Th} / \mathrm{He}$ on apatite and zircon) in high-temperature and high-pressure metamorphic units, which were exhumed during the first stage of extension, are dominantly Serravalian-Tortonian, over the whole Aegean (Brix et al., 2002; Wuthrich, 2009; Philippon et al., 2012; Marsellos et al., 2014). This indicates that metamorphic rocks of the SRCC, the CBU-CCCC and Peloponnese-Crete, whose onsets of exhumation were different, were reaching the surface in Middle-Late Miocene.

The mode of extension during this second stage of Aegean extension is in strong contrast with the one that characterizes the first stage. Extension passed in Middle Miocene from the core complex mode to the wide rift mode (Buck, 1991; Brun, 1999), as demonstrated by the deposition of extensional or transtensional Neogene basins across the whole Aegean, offshore as well as onshore. The interruption of ductile exhumation in Middle Miocene, in all types of metamorphic rocks (HT as well as HP) whatever their age of onset, as well as the segmentation of the metamorphic units and the deposition of Neogene basins on top of them suggest that the transition between the two modes of extension was not progressive and likely occurred in a rather short delay. 


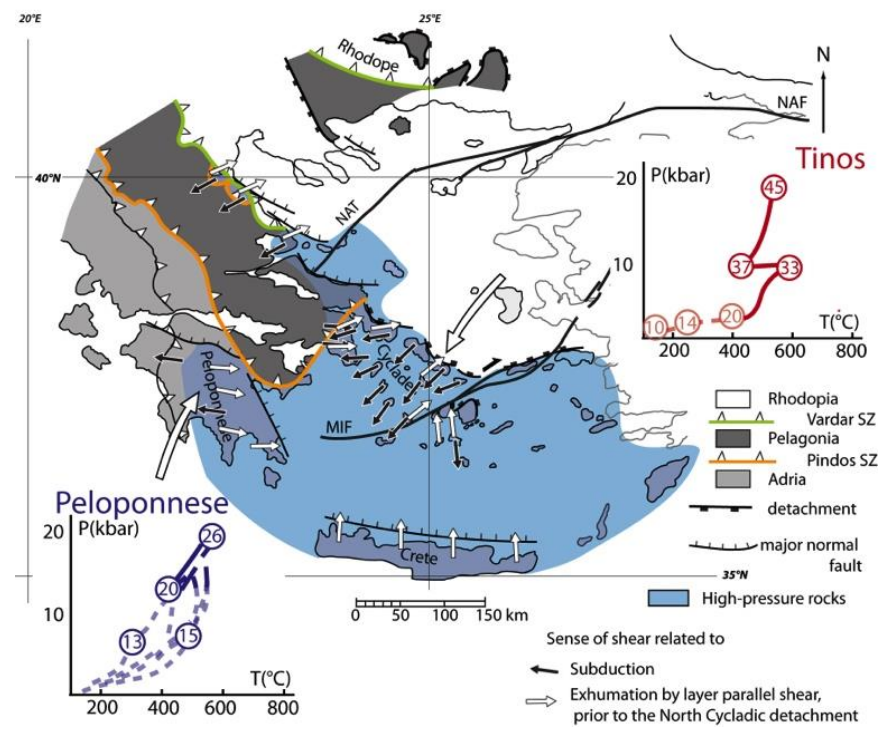

Figure 3 - The HP metamorphic domain of Adria and Pelagonia blocks with corresponding

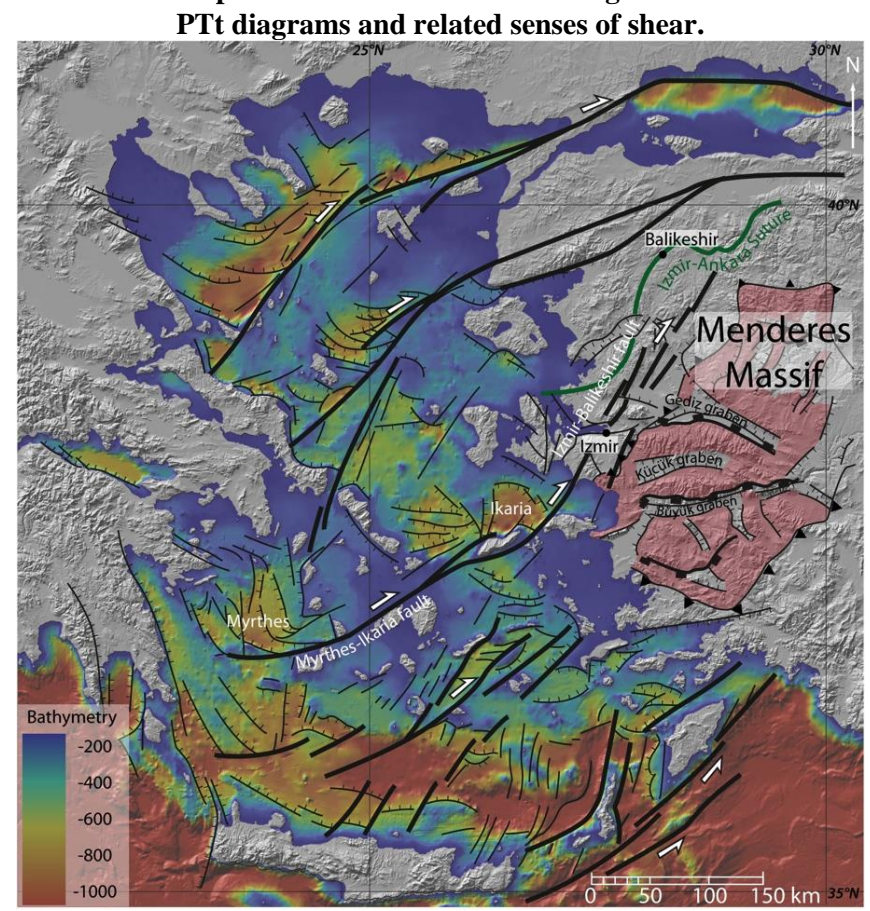

Fig. 4 - Major strike-slip faults and Neogene sedimentary basins in the Aegean Sea, as displayed by Aegean Sea bathymetry. 
The Myrthes-Ikaria fault (MIF) (Philippon et al., 2012) that cut trough the whole Cyclades domain is the offshore extend of the onshore Ismir-Balikeshir transfer zone (IBTZ) (Sozbilir et al., 2010; Ersoy et al., 2012; Uzel et al., 2013) (Fig. 4). Lower (?)-Late Miocene sedimentary-volcanic basins were deposited in this transtensional corridor, located at the northwestern border of the Menderes Massif (Ersoy et al., 2012). Simultaneously, grabens developed in the Menderes, accommodating a NE-SW direction of stretching. Over $450 \mathrm{~km}$, from Myrthes Basin to Balikeshir, this dextral strike-slip fault zone was active since Middle Miocene -i.e. around $10 \mathrm{My}$ before the arrival of the NAT in the North Aegean. Whereas there is no direct evidence to identify when displacements ceased on this fault zone, it can be hypothesized that this occurred around $5 \mathrm{Ma}$ when the NAF fully localized (Şengör $e$ t al., 2005), in agreement with the youngest ages of exhumation recorded by low-temperature thermochronology in the Cyclades (Philippon et al., 2014).

\section{Discussion-Conclusion: Acceleration of slab rollback}

The restoration of displacements using the numerous data sets available (paleomagnetism, kinematic indicators and geochronology) (Brun and Sokoutis, 2010 and re-evaluation by Brun et al., 2012) shows that an acceleration of trench retreat started in Middle Miocene (Fig.5). The rate of trench retreat that was rather low, around $0.6 \mathrm{~cm} . \mathrm{y}^{-1}$, during the first stage of extension increased to around $1.7 \mathrm{~cm} \cdot \mathrm{y}^{-1}$ between Middle Miocene and Pliocene, reaching $3.2 \mathrm{~cm} \cdot \mathrm{y}^{-1}$ during the last $5 \mathrm{Ma}$.

This acceleration of trench retreat (i.e. extensional boundary displacement), first by a factor 2 after Middle Miocene and then by a factor 5 after Pliocene, was more likely responsible for the observed change in the mode of extension, from localized to distributed - i.e. from core complex to wide rift (Buck, 1991; Brun, 1999; Tirel et al., 2006, 2008; Kydonakis et al., 2015).

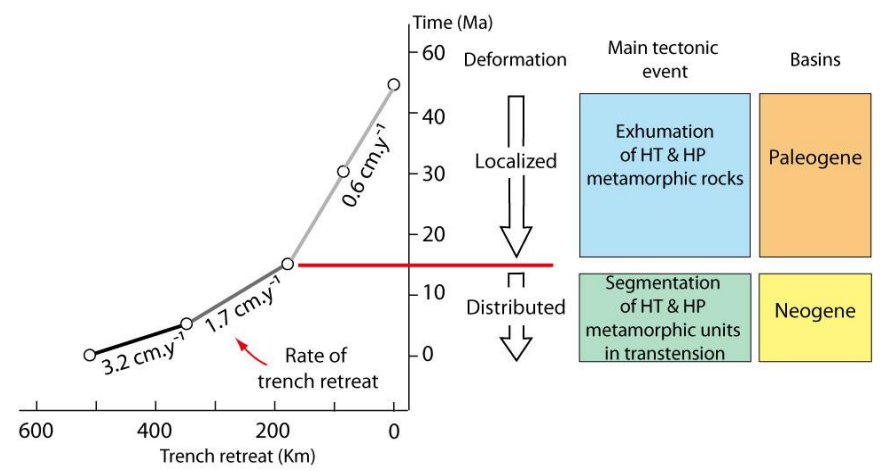

Fig. 5 - Modes of extension as a function of the rate of trench retreat.

The acceleration of trench retreat is more likely related to the Hellenic slab tearing whose rather complex geometry was recently evidenced by S-wave tomography (Salaün et al., 2012). Whereas the exact timing of slab tearing is difficult to constrain, the sudden change in the mode of extension, which is associated with the acceleration of slab retreat, strongly supports that slab tearing should have started to develop earlier, possibly in Early Miocene, to become fully efficient from $15 \mathrm{Ma}$ onward.

The transtensional deformation pattern (Fig. 4) that results from the interaction between Hellenic trench retreat and Anatolia westward displacement and that is still active in the Aegean took place in Middle Miocene, as previously argued by Dewey and Şengör (1979) and Şengör et al. (2005). Consequently, the westward displacement of Anatolia was coeval with the acceleration of trench retreat. Whereas the North Anatolian Fault plays a major role in the present-day kinematic pattern, the 450 km-long Myrthes-Ikaria Fault-IBTF (Fig. 4) was the first large dextral strike-slip fault zone 
to develop. Its location close to the Izmir-Ankara suture zone and parallel to it strongly suggests that the suture zone was acting as weak zone able to localize displacements at the onset of Anatolia westward displacement; as illustrated by the laboratory experiments of Philippon et al. (2014).

However, this interaction between two plate boundary displacements raises a fundamental issue: What is the dynamic relationship between slab tearing and Anatolia displacement? Which one controlled the development of the other?

\section{References}

Armijo, R., Meyer, B., Hubert, A. and Barka, A., 1999. Westward propagation of the north Anatolian into the northern Aegean: timing and kinematics, Geology, 27, 267-270.

Brix, M.R., Stöckhert, B., Seidel, E., Theye, T., Thomson, S.N. and Küster, M., 2002. Thermobarometric data from a fossil zircon partial annealing zone in high pressure-low temperature rocks of eastern and central Crete, Greece, Tectonophysics, 349, 309-326.

Brun, J.-P., 1999. Narrow rifts versus wide rifts: Inferences for the mechanics of rifting from laboratory experiments. Philosophical Transactions of the Royal Society, London, Ser. A 357, 695-712.

Brun, J.-P. and Faccenna, C., 2008. Exhumation of high-pressure rocks driven by slab rollback, Earth and Planetary Science Letters, 272, 1-7, doi: 10.1016/j.epsl.2008.02.038.

Brun, J.-P. and Sokoutis, D., 2007. Kinematics of the Southern Rhodope Core Complex (north Greece), International Journal of Earth Sciences, 96, 1079-1099.

Brun, J.-P. and Sokoutis, D., 2010. 45 m.y. of Aegean crust and mantle flow driven by trench retreat, Geology, 38, 815-818, doi: 10.1130/G30950.1.

Brun, J.-P., Tirel, C., Philippon, M., Burov, E., Faccenna, C., Gueydan, F. and Lebedev, S., 2012. On the role of horizontal displacements in the exhumation of high pressure metamorphic rocks, Geophysical Research Abstracts, 14, EGU2012-9381.

Buck, W.R., 1991. Modes of continental lithospheric extension, Journal of Geophysical Research, 96(B12), 20161-20178.

Carras, N. and Georgala, D., 1998. Upper Jurassic to Lower Cretaceous Carbonate Facies of African Affinities in a Peri-European Area: Chalkidiki Peninsula, Greece, Facies, 38, 153-164.

Channell, J.E.T. and Kozur, H., 1997. How many oceans? Meliata, Vardar, and Pindos oceans in Mesozoic Alpine paleogeography, Geology, 25, 183-186.

Dercourt, J., Ricou, L.E. and Vrielynck, B., 1993. Atlas Tethys Paleoenvironmental Maps, BeicipFranlab, Deschamps, R., Hamon, Y., Darre, T. and Gorini, C., 2013. Caractérisation des séries lacustres du Miocène Supérieur de l'Ile de Samos. Un exemple de paléolac alcalin et salin, In: 14eme Congrès Français de Sédimentologie, Paris (Ed. ASF), 73, 118.

Dewey, J.F. and Şengör, A.C., 1979. Aegean and surrounding regions: complex multiplate and continuum tectonics in a convergent zone, Geological Society of America Bulletin, 90, 84-92.

Doutsos, T., Koukouvelas, I., Zelilidis, A. and Kontopoulos, N., 1994. Intracontinental wedging and post-orogenic collapse in Mesohellenic trough, Geologische Rundschau, 83, 257-275.

Ersoy, E.Y., Helvaci, C., Uysal, I., Karaoğlu, Ö., Palmer, M.R. and Dindi, F., 2012. Petrogenesis of the Miocene volcanism along the Izmir-Balıkesir Transfer Zone in western Anatolia, Turkey: implications for origin and evolution of potassic volcanism in postcollisional areas, Journal of Volcanology and Geothermal Research, 241-242, 21-38.

Faccenna, C., Jolivet, L., Piromallo, C. and Morelli, A., 2003. Subduction and the depth of convection in the Mediterranean mantle, Journal of Geophysical Research, 108(B2), 2099. http://dx.doi.org/10.1029/2001JB001690.

Faccenna, C., Becker, T.W., Auer, L., Billi, A., Boschi, L., Brun, J.-P., Capitanio, F.A., Funiciello, F., Horvàth, F., Jolivet, L., Piromallo, C., Royden, L., Rossetti, F. and Serpelloni, E., 2014. Mantle dynamics in the Mediterranean, Review of Geophysics, doi: 10.1002/2013RG000444.

Ferrière, J., Reynaud, J.-Y., Pavlopoulos, A., Bonneau, M., Migiros, G., Chanier, F., Proust, J.-N. and Gardin, S., 2004. Geologic evolution and geodynamic controls of the Tertiary intramontane piggyback Meso-Hellenic basin, Greece, Bulletin de la Société Géologique de 
France, 175, 361-381.

Görür, N. and Okay, A.I., 1996. A fore-arc origin for the Thrace Basin, NW Turkey, Geologische Rundschau, 85, 662-668.

Hollenstein, C., Müller, M.D., Geiger, A. and Kahle H.-G., 2008. Crustal motion and deformation in Greece from a decade of GPS measurements, 1993-2003, Tectonophysics, 449, 17-40, http://dx.doi.org/10.1016/j.tecto.2007.12.006.

Hubert-Ferrari, A., King, G., Manighetti, I., Armijo, R., Meyer, B. and Tapponnier, P., 2003. Longterm Elasticity in the Continental Lithosphere; Modelling the Aden Ridge Propagation and the Anatolian Extrusion Process, Geophysical Journal International, 153, 111-132.

Jolivet, L. and Brun, J.-P., 2010. Cenozoic geodynamic evolution of the Aegean, International Journal of Earth Sciences, 99 (1), 109-138, doi: 10.1007/s00531-008-0366-4.

Jolivet, L. and Faccenna, C., 2000. Mediterranean extension and the Africa-Eurasia collision, Tectonics, 19, 1095-1106.

Jolivet, L., Trotet, F., Monié, P., Vidal, O., Goffé, B., Labrousse, L., Agard, P. and Ghorbal, B., 2010 Along-strike variations of P-T conditions in accretionary wedges and syn-orogenic extension, the HP-LT Phyllite-Quartzite Nappe in Crete and the Peloponnese, Tectonophysics, 480, 133-148, doi: 10.1016/j.tecto.2009.10.002.

Jolivet, L., Faccenna, C., Huet, B., Labrousse, L., Le Pourhiet, L., Lacombe, O., Lecomte, E., Burov, E., Denèle, Y., Brun, J.-P., Philippon, M., Paul, A., Salaün, G., Karabulut, H., Piromallo, C., Monié, P., Gueydan, F., Okay, A.I., Oberhänsli, R., Pourteau, A., Augier, R., Gadenne, L. and Driussi, O., 2013. Aegean tectonics: Strain localisation, slab tearing and trench retreat, Tectonophysics, 597, 1-33, doi: 10.1016/j.tecto.2012.06.011.

Kilias, A., Falalakis, G., Sfeikos, A., Papadimitriou, E., Vamvaka, A. and Gkarlaouni, C., 2013. The Thrace basin in the Rhodope province of NE Greece - A tertiary supradetachment basin and its geodynamic implications, Tectonophysics, 595-596, 90-105.

Koukouvelas, I.K. and Aydin, A., 2002. Fault structure and related basins of the North Aegean Sea and its surroundings, Tectonics, 21, 1046. http://dx.doi.org/10.1029/2001TC901037.

Kydonakis, K., Brun, J.-P. and Sokoutis, D., 2015a. North Aegean core complexes, the gravity spreading of a thrust wedge, Journal of Geophysical Research, Solid Earth, 120, doi: 10.1002/2014JB011601.

Le Pichon, X. and Angelier, J., 1981. The Aegean Sea. Philos. Philosophical Transactions of the Royal Society, London, Ser. A 300, 357-372.

Lyberis, N., 1984. Tectonic evolution of the North Aegean trough, Geological Society, London, Special Publications, 17, 709-725.

Marsellos, A.E., Min, K. and Foster, D.A., 2014. Rapid Exhumation of High-Pressure Metamorphic Rocks in Kythera-Peloponnese (Greece) Revealed by Apatite (U-Th)/He Thermochronology, The Journal of Geology, 122, 381-396.

Mascle, J. and Martin, L., 1990. Shallow structure and recent evolution of the Aegean Sea: A synthesis based on continuous reflection profiles, Marine Geology, 94, 271-299. doi: 10.1016/0025-3227(90)90060-W.

McClusky, S., Balassanian, S., Barka, A., Demir, C., Ergintav, S., Georgiev, I., Gurkan, O., Hamburger, M., Hurst, K., Kahle, H., Kastens, K., Kekelidze, G., King, R., Kotzev, V., Lenk, O., Mahmoud, S., Mishin, A., Nadariya, M., Ouzounis, A., Paradissis, D., Peter, Y., Prilepin, M., Reilinger, R., Sanli, I., Seeger, H., Tealeb, A., Toksöz, M.N. and Veis, G., 2000. Global Positioning System constraints on plate kinematics and dynamics in the eastern Mediterranean and Caucasus, Journal of Geophysical Research, Solid Earth, 105, 5695-5719.

McKenzie, D.P. 1972. Active tectonics of the Mediterranean region. Geophysical Journal of the Royal Astronomical Society, 30, 109-185.

McKenzie, D.P., 1978. Active tectonics of the Alpine Himalayan Belt, the Aegean Sea and surrounding regions. Geophysical Journal of the Royal Astronomical Society, 55, 217-252.

Mercier, J.-L., Sorel, D. and Simeakis, K., 1987. Change in the state of stress in the overriding plate of a subduction zone: the Aegean Arc from the Pliocene to the present, Annales Tectonicae, 1, 20-39. 
Mercier, J.-L., Sorel, D., Vergely, P. and Simeakis, K., 1989. Extensional tectonic regimes in the Aegean basins during the Cenozoic, Basin Research, 2, 49-71.

Müller, M.D., Geiger, A., Kahle, H.-G., Veis, G., Billiris, H., Paradissis, D. and Felekis, S., 2013. Velocity and deformation fields in the North Aegean domain, Greece, and implications for fault kinematics, derived from GPS data 1993-2009, Tectonophysics, 597-598, 34-49. http://dx.doi.org/10.1016/j.tecto.2012.08.003.

Philippon, M., Brun, J.P. and Gueydan, F., 2012. Deciphering subduction from exhumation in the segmented Cycladic Blueschist Unit (Central Aegean, Greece), Tectonophysics, 524, 116134, doi:10.1016/j.tecto.2011.12.025.

Philippon, M., Brun, J.-P., Gueydan, F. and Sokoutis, D., 2014. The interaction between Aegean back-arc extension and Anatolia escape since Middle Miocene, Tectonophysics, 631, 176188, doi:10.1016/j.tecto.2014.04.039.

Piromallo, C. and Morelli, A., 2003. P wave tomography of the mantle under the AlpineMediterranean area, Journal of Geophysical Research, Solid Earth, 108(B2), 2065.

Robertson, A., 2004. Development of concepts concerning the genesis and emplacement of Tethyan ophiolites in the Eastern Mediterranean and Oman regions, Earth-Science Reviews, 66, 331-387.

Roussos, N., 1994. Stratigraphy and paleogeographic evolution of Palaeocene molassic basins of N. Aegean, Bulletin of the Geological Society of Greece, XXX, 275-294.

Royden, L.H., 1993. The tectonic expression slab pull at continental convergent boundaries, Tectonics, 12, 629-638.

Sakellariou, D., Mascle, J. and Lykousis, V., 2013. Strike slip tectonics and transtensional deformation in the Aegean region and the Hellenic arc: preliminary results, Bulletin of the Geological Society of Greece, XLVII, Proceedings of the 13th International Congress, Chania, Sept. 2013.

Salaün, G., Pedersen, H., Paul, A., Farra, V., Karabulut, H., Hatzfeld, D., Childs, D.M., Pequegnat, C. and the SIMBAAD Team, 2012. High-resolution surface wave tomography beneath the Aegean-Anatolia region: constraints on upper mantle structure, Geophysical Journal International, 190, 406-420, http://dx.doi.org/10.1111/j. 1365-246X.2012.05483.x.

Sengör, A.M.C., Tüysüz, O., Imren, C., Sakınç, M., Eyidogan, H., Görür, N., Le Pichon, X. and Rangin, C,. 2005. The North Anatolian Fault: A New Look, Annual Review of Earth and Planetary Sciences, 33, 37-112.

Siyako, M. and Huvaz, O., 2007. Eocene stratigraphic evolution of the Thrace Basin, Turkey, Sedimentary Geology, 198, 75-91.

Sözbilir, H., Sarı, B., Uzel, B., Sümer, Ö. and Akkiraz, S., 2011. Tectonic implications of transtensional supradetachment basin development in an extension-parallel transfer zone: the Kocaçay Basin, western Anatolia, Turkey, Basin Research, 23, 423-448, http://dx.doi.org/10.1111/j.1365-2117.2010.00496.x.

Tirel, C., Brun, J.-P. and Sokoutis, D., 2006. Extension of thickened and hot lithospheres: Inferences from laboratory modeling, Tectonics, 25, TC1005, doi: 10.1029/2005TC001804.

Tirel, C., Brun, J.-P., Burov, E., Wortel, M. and Lebedev, S., 2013. A plate tectonics oddity: Caterpillar-walk exhumation of subducted continental crust, Geology, 41, 555-558.

Uzel, B, Sözbilir, H., Özkaymak, C, Kaymakcı, N. and Langereis, C.G., 2013. Structural evidence for strike-slip deformation in the İzmir-Balıkesir transfer zone and consequences for late Cenozoic evolution of western Anatolia (Turkey), Journal of Geodynamics, 65, 94-116.

Widiyantoro, S., van der Hilst, R.D. and Wenzel, F., 2004. Deformation of the Aegean Slab in the Mantle Transition Zone, International Journal of Tomography and Statistics, D04, 1-14. December 2004 ISSN 0972-9976.

Wortel, M.J.R. and Spakman, W., 2000. Subduction and slab detachment in the MediterraneanCarpathian region, Science, 290, 1910-1917.

Wuthrich, E., 2009. Low temperature thermochronology of the North Aegean Rhodope Massif, Ph.D. thesis, Swiss Federal Institute of Technology, Zurich. 